\title{
Identifikasi Awal Tujuan Wisata di Provinsi Sulawesi Utara bagi Kajian Manajemen Pariwisata
}

\author{
Preliminary Identification of Tourism Destination in North Sulawesi \\ Province for Tourism Management Analysis
}

\author{
Olivia Moningka ${ }^{1, a)}$ \& Hitapriya Suprayitno ${ }^{2, b)}$ \\ 1) Jurusan Teknik Sipil, Politeknik Negeri Manado (Polimdo), Manado. \\ ${ }^{2)}$ Departemen Teknik Sipil, Institut Teknologi Sepuluh Nopember (ITS), Surabaya. \\ Koresponden : a)oliviamoningka@gmail.com \& ${ }^{\text {b) }}$ suprayitno.hita@gmail.com.
}

\begin{abstract}
ABSTRAK
Sumbangan sektor pariwisata bagi ekonomi daerah dan ekonomi nasional sangat signifikan. Oleh karena itu sektor pariwisata harus selalu dijaga keberadaannya agar selalu bisa berfungsi dengan baik dan semakin berkembang. Untuk itu Manajemen Pariwisata harus selalu dikembangkan. Langkah pertama adalah mengidentifikasi Destinasi Wisata di Provinsi Sulawesi Utara. Hasil identifikasi awal menunjukkan bahwa, dewasa ini, Destinasi Wisata Provinsi Sulawesi Utara banyak terdapat didaerah Minahasa. Destinasi Wisata yang ada cukup bervariasi dari Obyek Wisata Alam, Wisata Agrowisata, Wisata Budaya, Wisata Religi, dan Wisata Kuliner yang beragam. Destinasi Wisata yang terpopuler adalah Taman Laut Nasional Bunaken, Taman Nasional Tangkoko, Kota Tomohon, Danau Linow, Danau Tondano, Pasar Ektrim Tomohon, Bukit Kasih, dan Kota Manado. Jumlah Wisatawan Manca Negara pada kurun waktu Tahun 2014-2017 tumbuh dengan sangat pesat dengan asal negara didominasi oleh Tiongkok. Hal ini terutama disebabkan oleh dibukanya rute penerbangan langsung dari Tiongkok ke Manado.
\end{abstract}

Kata Kunci : manajemen aset fasilitas, identifikasi destinasi wisata, Sulawesi Utara.

\section{PENDAHULUAN}

Pariwisata penting bagi perekonomian. Sumbangan pariwisata bagi ekonomi besar. Pada skala dunia Sektor Pariwisata menyumbang sekitar 10,4\% PNB (WWTC 2018). Di Indonesia, sumbangan Sektor Pariwisata, pada tahun 2004 - 2009, hanya berada pada kisaran 3\% PDB, akan tetapi Sektor Pariwisata tumbuh dua kali lipat pertumbuhan ekonomi nasional (Mudrikah et al 2014). Pada daerah dengan kegiatan pariwisata yang sangat tinggi, seperti di Provinsi Bali, Sektor Pariwisata bisa menyumbang 30\% PDRB (Sanjaya 2006).

Di Indonesia, Sektor Pariwisata sangat dipentingkan. Indonesia mempunyai unit pemerintah yang khusus menangani pariwista yakni Kementerian Pariwisata. Indonesia juga mempunyai Undang-Undang Pariwisata dan turunannya. Pemerintahan saat ini juga mempunyai Program Nasional Pengembangan 10 Destinasi Pariwisata Nasional dan 25 Kawasan Strategis Pariwisata. Didalam pengembangan Pariwisata tersebut diperhatikan pengembangan unsur-unsur Layanan Pariwisata, yakni : obyek wisata, aksesibilitas, hotel, restoran, toko cindera mata, serta biro pariwisata. Pengembangan ini, diharapkan pada akhirnya bisa meningkatkan pendapatan penerimaan masyarakat. Pariwisata adalah Sektor Ekonomi yang sangat murah dan mudah untuk dikembangkan, karena banyak infrastruktur dan fasilitas pariwisata yang bisa dikembangkan oleh masyarakat pelaku pariwisata (Anonim 2017, Thaib 2017, Wahyuni 2018).

Provinsi Sulawesi Utara, terletak diujung utara Indonesia, mempunyai Destinasi Pariwisata yang sangat terkenal, yaitu : pulau Bunaken, kota Tomohon dan yang lain. Pariwisata di 
Sulawesi Utara bisa menjadi kegiatan ekonomi yang sangat penting. Untuk itu, kepariwisataan di Sulawesi Utara perlu dikelola dengan baik agar selalu bisa berfungsi dan berkembang baik. Untuk itu diperlukan Konsep Manajemen Pariwisata bagi Provinsi Sulawesi Utara.

Manajemen Pariwisata bisa didekati dari prinsip Manajemen Aset Infrastruktur dan Fasilitas. Tujuan utama manajemen ini adalah untuk mengelola agar Infrastruktur dan Fasilitas bisa selalu berfungsi dan berkembang dengan baik, agar bisa melayani Permintaan yang ada dan yang akan timbul (Soemitro \& Suprayitno 2018, Suprayitno \& Soemitro 2018).

Langkah pertama untuk mewujudkan hal tersebut adalah melakukan Identifikasi Awal Destinasi Wisata di Provinsi Sulawesi Utara. Makalah ini menyampaikan hasil penelitian Identifikasi Awal tersebut.

\section{METODA PENELITIAN}

Penelitian tentang Identifikasi Awal Destinasi Wisata Sulawesi Utara dilakukan dengan menggunakan urutan berpikir sebagai berikut : penentuan latar belakang, penentuan tujuan, penentuan metoda, studi pustaka, melakuan analisis, menyusun kesimpulan. Sesuai dengan tujuan pemakaian Data Identifikasi, yaitu guna merumuskan Survei Lanjutan dalam rangka Pnyusunan Rencana Pengembangan Pariwisata Sulawesi Utara, maka sifat Identifikasi ditujukan untuk mengumpulkan Destinasi Wisata sebanyak mungkin dengan disertai data umum tentang jenis destinasi wisata, lokasi, pencapaiahn, popularitas. Pengumpulan Data dimulai dari pemetaan lokasi, observasi pendahuluan destinasi wisata, dilengkapi dengan wawancara biro perjalanan.

\section{STUDI PUSTAKA}

\section{Pariwisata}

Pariwisata adalah berbagai macam kegiatan wisata dan didukung berbagai fasilitas serta layanan yang disediakan oleh masyarakat, pengusaha, Pemerintah Daerah dan Pemerintah Pusat. Wisata adalah kegiatan perjalanan oleh seseorang atau sekelompok orang dengan mengunjungi tempat tertentu untuk tujuan rekreasi, pengembangan pribadi, atau mempelajari daya tarik keunikan daya tarik wisata yang dikunjungi dalam jangka waktu sementara (UU 10/09). Dengan begitu didalam Sistem Pariwisata melibatkan beberapa komponen : wisatawan, destinasi wisata, sistem transportasi, rumah makan, toko souvenir, hotel, biro pariwisata, unit pemerintah urusan wisata.

\section{Klasifikasi Pariwisata}

Salah satu aspek sangat penting dalam memahami Pariwisata, untuk bisa mengelola dengan baik, adalah Klasifikasi Pariwisata. Pariwisata bisa diklasifikasikan berdasarkan wisatawan, perjalanan wisata, tujuan wisata, dan destinasi wisata. Setiap klas atau katagori mempunyai ciri khas sendiri yang bisa sangat berbeda satu dengan yang lain, sehingga mempunyai tingkah-laku wisata yang berbeda-beda. Hal ini akan memerlukan Layanan Pariwisata yang bisa berbeda (Thaib 2017).

Wisatawan bisa diklasifikasikan kedalam wistawan manca negara (wisman) dan wisatawan domestik (wisdom), kedalam golongan ekonomi wisatawan, kedalam asal usul daerah, kedalam jumlah dalam kelompok, juga kedalam bahasa wisatawan (Thaib 2017; Wahyuni 2018).

Perjalanan Wisata bisa digolongkan kedalam berwisata secara perorangan atau kelompok, kedalam lama perjalanan wisata, kedalam transportai perjalanan datang dan pergi, dan lain sebagainya (Thaib 2017; Wahyuni 2018).

Destinasi Wisata bisa diklasifikasikan kedalam Destinasi Wisata alam atau buatan. Selanjutnya kedua jenis Destinasi Wisata bisa diklasifikasikan kedalam beberapa Destinasi 
Wisata, antara lain : wisata alam, wisata budaya, wisata olah raga, wisata kuliner, wisata MICE, dan yang lain (Thaib 2017; Wahyuni 2018).

\section{Ekonomi Pariwisata}

Kegiatan Pariwisata sangat penting bagi ekonomi, baik pada tataran dunia, tataran negara, tataran provinsi, maupun tataran lokal. Beberapa kajian telah dilakukan tentang peran Pariwisata pada beberapa tataran tersebut diatas. Beberapa conoth hasil kajian disampaikan berikut ini.

Dilihat pada skala dunia, aspek Ekonomi Pariwisata secara garis besar bisa disampaikan sebagai berikut : Pariwisata menyumbangkan 10,4\% dari PNB, sektor Pariwisata mengalami pertumbuhan sebesar 4,6\%, 10\% pekerjaan didunia didukung oleh Pariwisata, akhir-akhir ini 20\% pekerjaan baru berada di Pariwisata (WWTC 2018).

Kajian pada Skala Nasional Indonesia menunjukkan bahwa pada tahun 2017, penerimaan devisa dari minyak sama dengan penerimaan devisa dari pariwisata. Sedangkan situasi untuk tahun 2019 diperkirakan bahwa devisa pariwisata lebih besar dari pada devisa minyak. Pada kurun waktu tahun 2013-2015, devisa pariwisata mempunyai urutan nomor 4, kemudian pada tahun 2016 devisa pariwisata berada pada posisi nomor 2. Pada tahun 2017, pertumbuhan pariwisata dunia adalah sebesar 6,4\%, pertumbuhan pada Kawasan Asean adalah sebesar 7\%, dan pertumbuhan unutk Indonesia adalah sebesar 24\%. Mengingat peran Pariwisata di Indonesia yang sedemikian penting, pada tahun 2017, Indonesia memutuskan bahwa Pariwisata merupakan salah satu Sektor Pembangunan utama. Untuk itu Indonesia akan mengembangkan 10 Destinasi Wisata Utama (Thaib 2017).

Kajian dampak Pariwisata bagi Ekonomi pada Skala Provinsi bisa disampaikan sebagai berikut. Di Provinsi Bali, pada tahun 1990an, sumbangan sektor pariwisata sebesar 30\% dari PDRB (Sanjaya 2006). Kajian yang lain menunjukkan bahwa kalau pariwisata berkembang, maka kinerja ekonomi membaik, juga pengembangan pariwisata berdampak negatif terhadap kemiskinan (Patera \& Suardana 2011). Suatu Kajian tentang Pengaruh Pariwisata terhadap Ekonomi Jawa Timur menunjukkan bahwa berapa parameter kegiatan pariwisata, yaitu : investasi hotel, jumlah kunjungan wisatawan, dan lama tinggal wisatawan berpengaruh positif terhadap PDRB, terutama parameter investasi hotel (Subardini 2017).

Kajian pada skala lokal di Kepulauan Seribu menunjukkan bahwa Pengembangan Ekowisata menghasilkan peningkatan ekonomi berupa : peningkatan pendapatan, dan peningkatan lapangan kerja (Aryunda 2011).

\section{Manajemen Pariwisata}

Manajemen Pariwisata adalah Ilmu atau Tindakan Pengelolaan Pariwisata. Mengingat Pariwisata melibatkan kegiatan menuju destinasi wisata, menikmati destinasi wisata, makanminum, membeli souvenir, menginap, maka didalam Manajemen Pariwisata terdapat beberapa tataran Manajemen Pariwisata sebagai berikut (TutorialsPoint 2016).

- Manajemen Destinasi Wisata

- Manajemen Biro Perjalanan Wisata

- Manajemen Hotel

- Manajemen Rumah Makan

- Manajemen Toko Suvenir

- Manajemen Angkutan Wisata

- Manajemen Wilayah Wisata oleh Pemerintah 


\section{IDENTIFIKSI AWAL OBYEK WISATA}

\section{Prinsip Dasar Analisis}

Hasil Identifikasi harus bisa dipakai bagi Studi Pengembanagn Manajemen Pariwisata. Dengan demikian analisis dimulai dengan Identifikasi Destinasi Wisata dan dilanjutkan dengan Klasifikasi Destinasi Wisata berdasarkan kaidah : lokasi, tipe obyek wisata, intensitas kunjungan.

\section{Gambaran Umum Provinsi Sulawesi Utara}

Provinsi Sulawesi Utara membentang dari utara ke arah barat daya, dimulai dari kepulauan yang terletak disebelah utara ujung utara pulau Sulawesi sampai dengan kawasan utara pulau Sulawesi. Dengan ibu kota Kota Manado, Provinsi Sulawesi Utara terbagi kedalam 4 wilayah kota dan 11 wilayah kabupaten. Keempat kota tersebut adalah Manado, Tomohon, Bitung, Kotamobagu. Kesebelas kabupaten tersebut adalah 4 Kabupaten Minahasa (Minahasa, Minahasa Utara, Minahasa Selatan, Minahasa Tenggara), 4 kabupaten Boolang Mongondow (Boolang Mongondow, BM Selatan, BM Timur, BM Utara) dan 3 kabupaten kepulauan : Sangihe, Talaud dan Siau Tagulandang Biaro.Jadi Sulawesi Utra terbagi kedalam tiga Daerah Budaya yang berbeda : Minahasa, Boolang Mongondow dan Sangihe Talaud.

\section{Identifikasi Destinasi Wisata}

Berdasarkan informasi yang didapat dari beberapa sumber terkait Wisata, praktis semua Destinasi Wisata Sulawesi Utara terletak di Kawasan Minahasa. Pada langkah Identifikasi ini, berhasil dikumpulkan 20 Destinasi Wisata sebagai berikut.

Tabel 1.Dua Puluh Destinasi Wisata di Sulawesi Utara

\begin{tabular}{|c|c|c|c|c|}
\hline Lokas i & No & ID & Des tinasi Wis ata & Katagori \\
\hline \multirow{8}{*}{ Kota Manado } & 1 & 1 & Taman Nasional Bunaken & Alam \\
\hline & 2 & 2 & Pantai Malalay ang & Sosial Budaya, Alam \\
\hline & 3 & 3 & Air Terjun Kimang Atas & Alam \\
\hline & 4 & 4 & Mus eum Negara Sulawesi Utara & Sosial Budaya \\
\hline & 5 & 5 & Kawas an Boulevard Manado & Kuliner \\
\hline & 6 & 6 & Monumen Yesus Memberkati & Minat Khusus \\
\hline & 7 & 7 & Jembatan Soekarno & Monumen \\
\hline & 8 & 8 & Pulau Siladen & Alam \\
\hline \multirow{3}{*}{ Kota Tomohon } & 1 & 9 & Kota Bunga & Sosial Budaya \\
\hline & 2 & 10 & Danau Linow & Alam \\
\hline & 3 & 11 & Gunung Mahawu & Alam \\
\hline \multirow{2}{*}{ Kota Bitung } & 1 & 12 & Taman Wisata Tandu Rusa & Alam \\
\hline & 2 & 13 & Pulau Lembeh & Alam \\
\hline \multirow{2}{*}{ Kab. Minahasa } & 1 & 14 & Danau Tondano & Alam \\
\hline & 2 & 15 & Bukit Kasih & Sosial Budaya \\
\hline \multirow{3}{*}{ Kab. Minahasa Utara } & 1 & 16 & Arung Jeram Sawangan & Minat Khusus \\
\hline & 2 & 17 & Waruga Sawangan & Sosial Budaya \\
\hline & 3 & 18 & Pulau Lihaga & Alam \\
\hline \multirow{2}{*}{ Kab. Minahasa Tenggara } & 1 & 19 & Taman Laut Tumbak & Alam \\
\hline & 2 & 20 & Air Konde & Alam \\
\hline
\end{tabular}




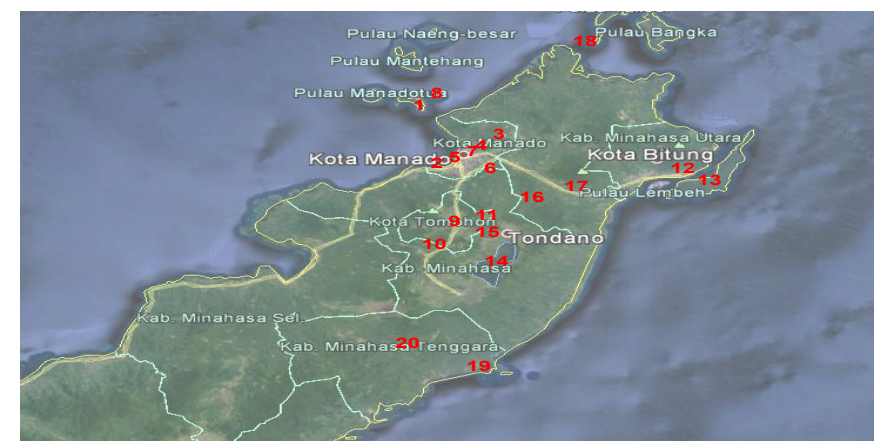

Gambar 1. Lokasi 20 Obyek Wisata Sulawesi Utara berikut.

Urain singkat kedua puluh Tujuan Wisata di Provinsi Sulawesi Utara disampaikan sebagai

1. Taman Nasional Bunaken

Bunaken adalah sebuah pulau seluas $8,08 \mathrm{~km}^{2}$ di Teluk Manado, dan merupakan bagian dari kota Manado. Taman Laut Bunaken adalah lokasi penyelaman terkenal di Manado. Keindahan pemandangan bawah laut yang indah, lengkap, serta keaslian tempat wisata snorkeling, membuat UNESCO menetapkan Taman Laut Bunaken menjadi warisan dunia.Tempat wisata taman bawah laut Bunaken ini memiliki berbagai macam biota laut, terumbu karang, dan ikan berwarna-warni yang cantik.

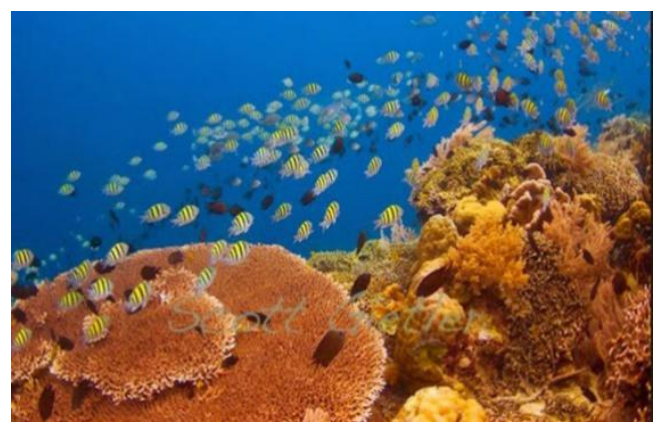

Gambar 2. Taman Nasional Bunaken

2. Pantai Malalayang Manado

Pantai Malalayang yang terletak di ujung selatan kota Manado Sulawesi Utara, memiliki banyak hal yang menarik untuk di nikmati. Diantaranya taman laut yang masih alami dengan berbagai jenis koral warna warni dan spesies ikan berbagai jenis. Untuk sampai di pantai ini, dibutuhkan waktu sekitar 10 menit dari pusat kota Manado dengan menggunakan angkutan umum. Jaraknya sekitar 4 kilometer saja. Pantai ini menjadi satusatunya tempat wisata rakyat yang murah meriah, karena aksesnya dekat dan mudah ditempuh. Menikmati pemandangan indahnya pantai sambil duduk dan menikmati kudapan pisang goreng menjadi andalan di pantai ini. Kontur bebatuan di pantai ini tidak membuat minat wisatawan untuk turun ke bawah dan merasakan bermain-main dengan air laut. Mengunjungi Pantai Malalayang sangat tepat saat hari mulai senja karena di pantai ini tersaji sunset yang indah.

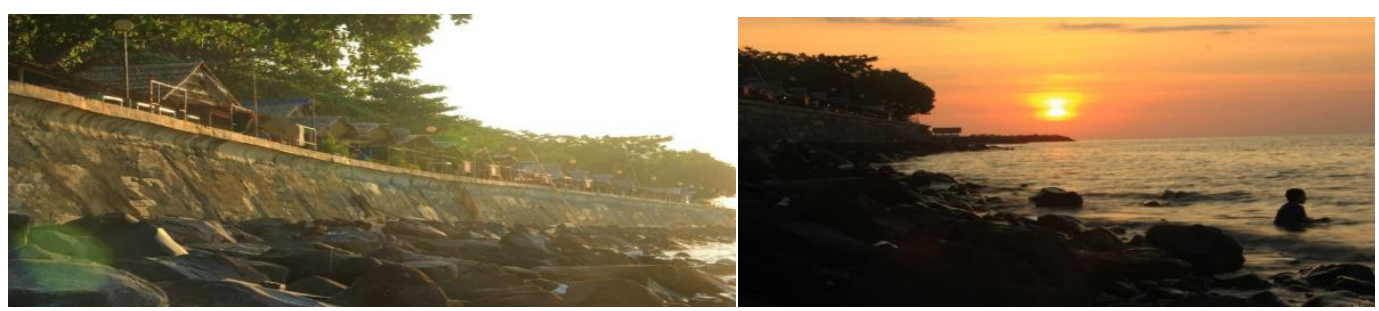

Gambar 3. Pantai Malalayang 


\section{Air Terjun Kimang Atas}

Air Terjun Kimang Atas terletak di kecamatan Mapanget. Obyek Wisata ini sudah banyak dikunjungi wisatawan lokal, dan bahkan wisatawan mancanegara. Air Terjun Kimang Atas hanya berjarak 30 menit dari jantung kota Manado. Obyek wisata ini memiliki panorama yang unik yakni air terjun yang memiliki 3 tingkat. Air terjun ini juga mempunyai air yang bening, bersih dan masih sangat alami sehingga tempat ini sangat cocok bagi yang mengidamkan tempat wisata yang masih perawan. Obyek wisata ini merupakan tempat yang cocok bagi para yang mendambakan nuansa berwisata yang nyaman dan tenang.

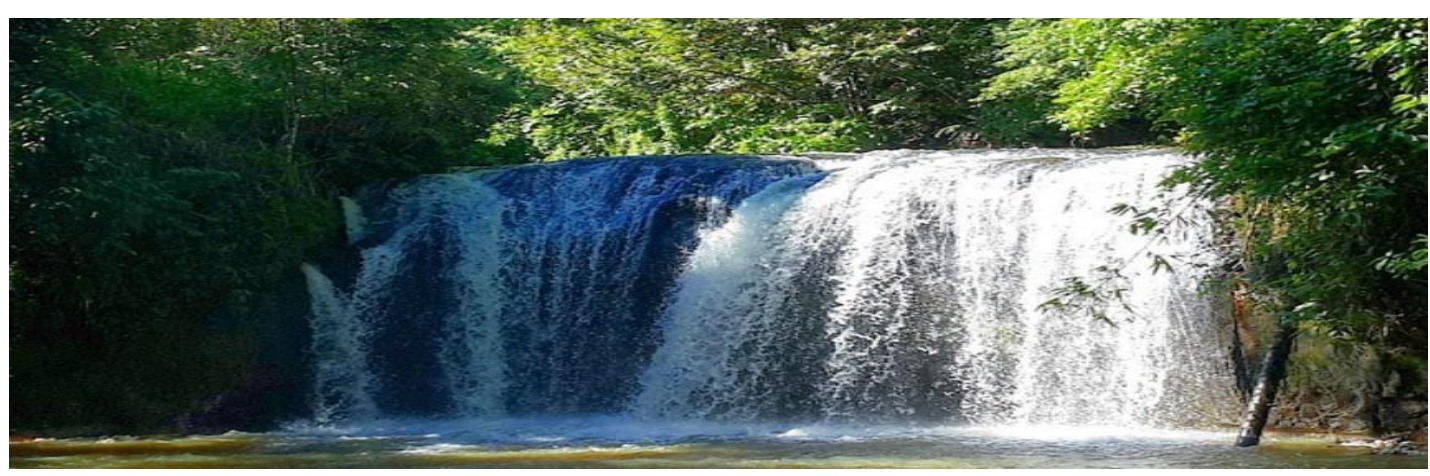

Gambar 4. Air Terjun Kimang Atas

4. Museum Negara Sulawesi Utara

Museum Negara Provinsi Sulawesi Utara merupakan media informasi tentang sejarah alam, manusia dan budaya Sulawesi Utara. Museum ini dibangun untuk mendokumentasikan segala hal yang berkaitan dengan sejarah alam, manusia dan kebudayaan di wilayah Provinsi. Cakupan peragaan museum ini cukup lengkap, yakni 10 jenis koleksi di antaranya geologika, biologika, arkeologika, historika, etnografika, filologika, seni rupa, dan teknologika. Museum ini diresmikan pada 9 Januari 1991 dan hingga kini telah mengumpulkan sekitar 2.810 koleksi. Dari total koleksi di atas, sekitar 500-an koleksi dipamerkan di gedung pameran tetap dan dapat dinikmati setiap hari kerja. Koleksi tersebut diperoleh dari daerah-daerah kabupaten dan kota di Sulawesi Utara, seperti Manado, Minahasa Selatan, Sangihe, Talaud, Sitaro, Bolaang Mongondow dan yang lain.

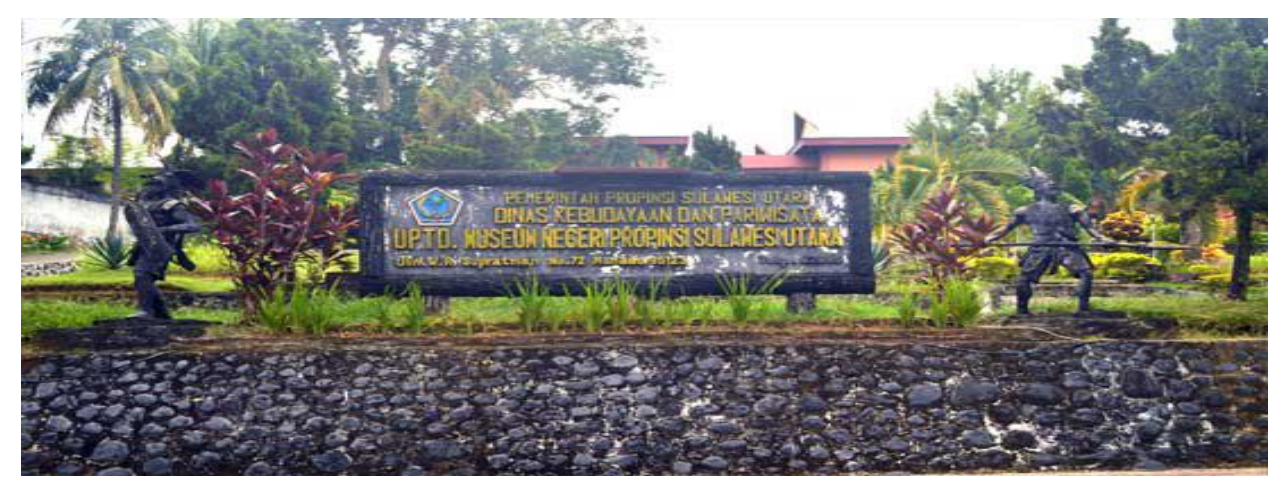

Gambar 5. Musium Negara Sulawesi Utara

5. Kawasan Boulevard Manado

Salah satu kawasan wisata di Kota Manado adalah Kawasan Boulevard. Pada malam hari, kawasan ini merupakan pusat kuliner yang tak hanya menghidangkan masakan Manado, tapi juga makanan populer Indonesia dengan harga yang relatif murah. Cafe, 
restoran, warung sampai penjual kaki lima ada di kawasan ini.Kawasan wisata ini mempresentasikan Manado sebagai kota wisata pantai dan kuliner, serta menjadi kawasan unggulan bagi Manado karena meningkatkan minat wisatawan untuk datang mengunjungi kota dan pantai di sepanjang Manado.Panorama alam seperti Pulau Manado Tua ditengah lautan bisa terlihat ketika sedang menikmati makanan. Jangan lewatkan pula pemandangan terjadinya matahari terbenam yang terlihat dengan jelas dari kawasan ini.

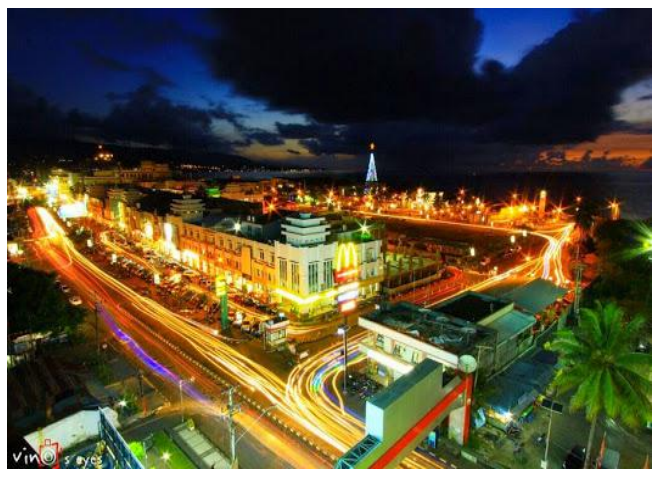

Gambar 6. Bulevard Manado

\section{Monumen Jesus Memberkati}

Monumen Yesus Memberkati, lebih dikenal sebagai Yesus Memberkati, dalam Bahasa Manado Yesus Kase Berkat terletak di Kota Manado. Patung itu berdiri setinggi 50 meter, dan terdiri dari penopang 20 meter dan patung 30 meter. Patung ini terbuat dari 25 ton serat logam dan 35 ton baja, dan terletak di puncak perumahan Citraland Manado. Patung ini memiliki kemiringan 20 derajat dan terbuat dari serat dan baja dan menjadi patung terbang pertama yang tertinggi di dunia. Patung ini telah menjadi ikon baru kota Manado. Pada tahun 2010, patung ini tertinggi ke 2 di Asia dan patung Yesus tertinggi ke4 di dunia. Patung tersebut dibangun sebagai ajakan untuk masyarakat Manado dan Sulawesi Utara untuk menyembah Allah.

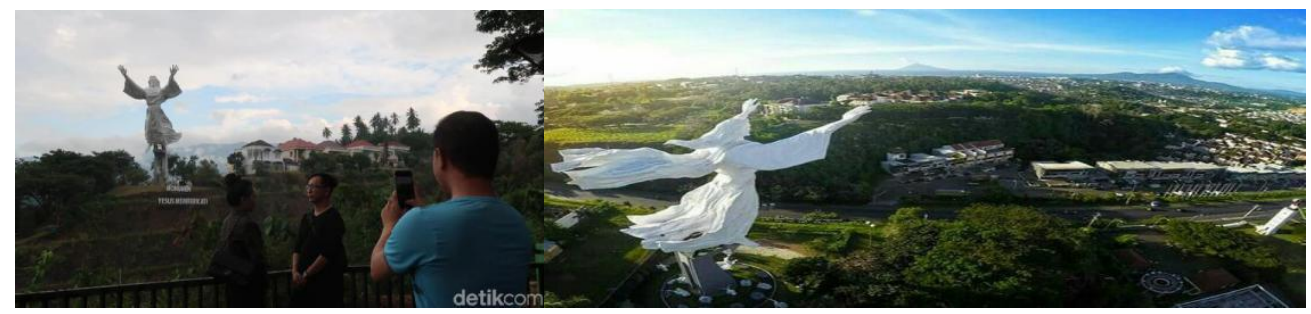

Gambar 7. Patung Yesus Memberkati

\section{Jembatan Soekarno}

Jembatan Soekarno di Kota Manado telah diresmikan pada Mei 2015, setelah sempat terbengkalai 12 tahun. Jembatan sepanjang 1,127 km dan menelan biaya Rp 300 miliar ini mempunyai pemandangan indah bila Anda berada di atasnya. Jembatan Soekarno masih menjadi objek dan lokasi untuk berswafoto. Dari lokasi ini bisa terlihat Gunung Klabat, Pulau Bunaken, Pulau Manado Tua, Pulau Nain, Teluk Manado, Kampung Pelangi, Patung Lilin, Pelabuhan Kapal ke Sanger Talaud Sitaro, Pasar Bersehati, dan gedung-gedung tinggi. 


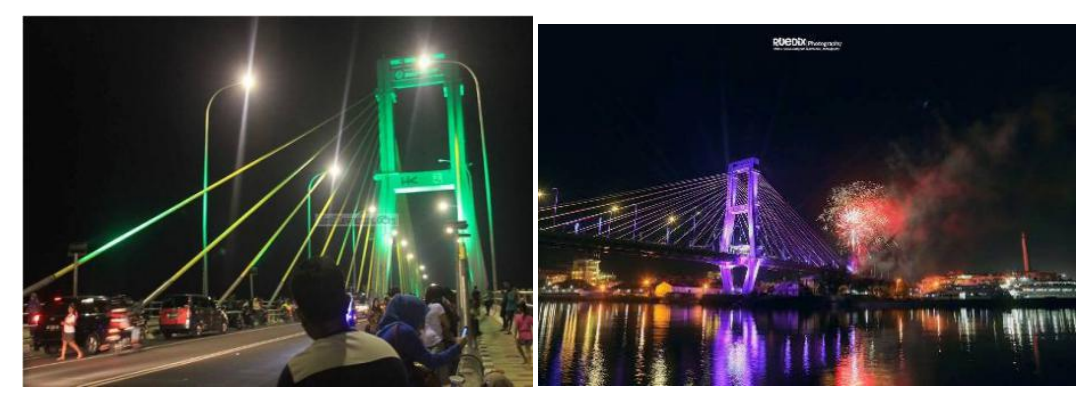

Gambar 8. Jembatan Soekarno

\section{Pulau Siladen}

Pulau Siladen terletak di sebelah timur laut Pulau Bunaken, dan dapat ditempuh selama 45 menit menggunakan kapal motor. Pulau Siladen memiliki luas sekitar 31,25 hektar yang dikelilingi oleh hamparan pasir putih dengan beragam pepohonan disepanjang bibir pantainya.Pulau Siladen sendiri terletak tidak jauh dari pulau Manado Tua yang merupakan salah satu tempat terbaik di Kota Manado untuk berlibur. Dikelilingi dengan pantai berpasir putih dan laut yang terdapat terumbu karang dengan berbagai biota laut yang beraneka ragam dengan berbagai macam bentuk dan warna sehingga membentuk taman laut yang sangat indah.
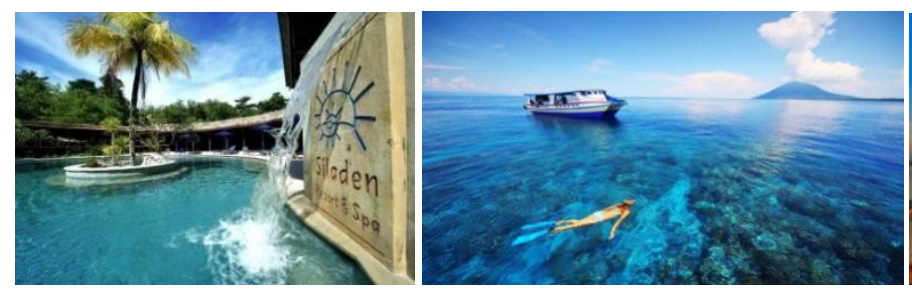

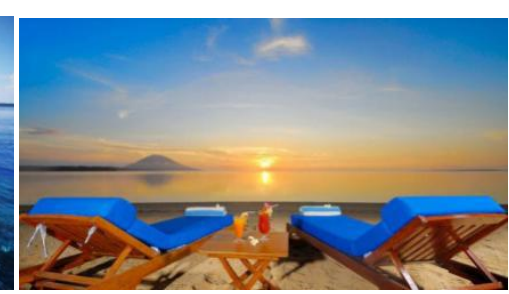

Gambar 9. Pulau Siladen

\section{Kota Bunga Tomohon}

Selain dikenal dengan wisata alam bawah lautnya, Sulawesi Utara juga memiliki sebuah Kota Bunga bernama Tomohon. Kota Tomohon terletak $22 \mathrm{~km}$ di sisi timur kota Manado. Saking terkenalnya, kota cantik ini juga memiliki acara pameran berkelas internasional bertajuk Tomohon International Flower Festival. Kota Bunga Tomohon ini mempunyai koleksi bunga yang sangat beragam. Kondisi tanahnya yang subur dan udaranya yang sejuk membuat tempat ini cocok untuk menanam segala jenis bunga. Tak heran jika kita dapat menjumpai banyak bunga dari tempat ini. Jika festival ini tiba, kota Tomohon bak hamparan bunga beraneka warna.Salah satu cara terbaik menikmati Tomohon adalah berkeliling menggunakan mobil. Atau Anda lebih baik berjalan kaki saja sambil menikmati udara Tomohon yang segar.

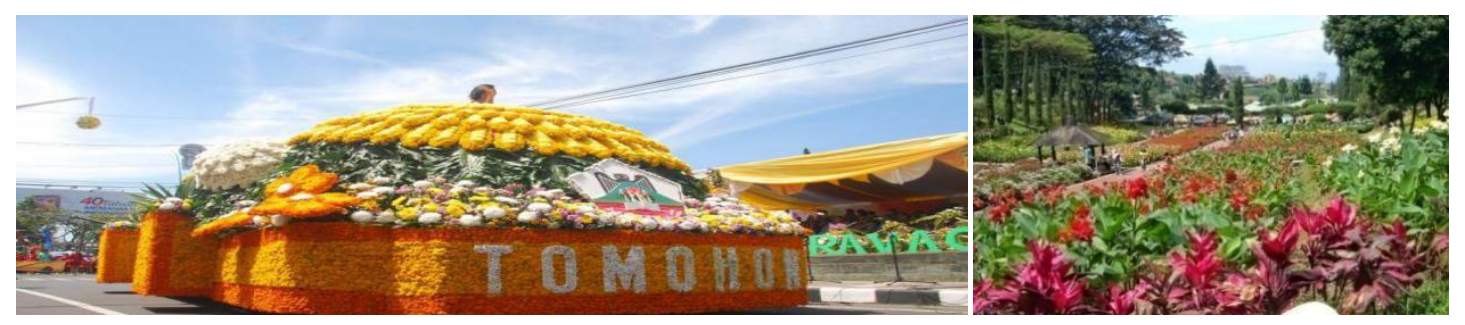

Gambar 10. Kota Bunga Tomohon

10. Danau Linow

Danau Linow terletak di kota Tomohon. Danau ini unik karena waktu siang, airnya berwarna-warni dalam tiga warna. Danau ini merupakan salah satu objek wisata yang menarik di Sulawesi Utara. Salah satu faasilitas yang paling menarik adalah Restoran di 
Tepi Danau. Selain itu terdapat pula resort, hotel, foodcourt dan tempat memanjakan diri seperti spa.

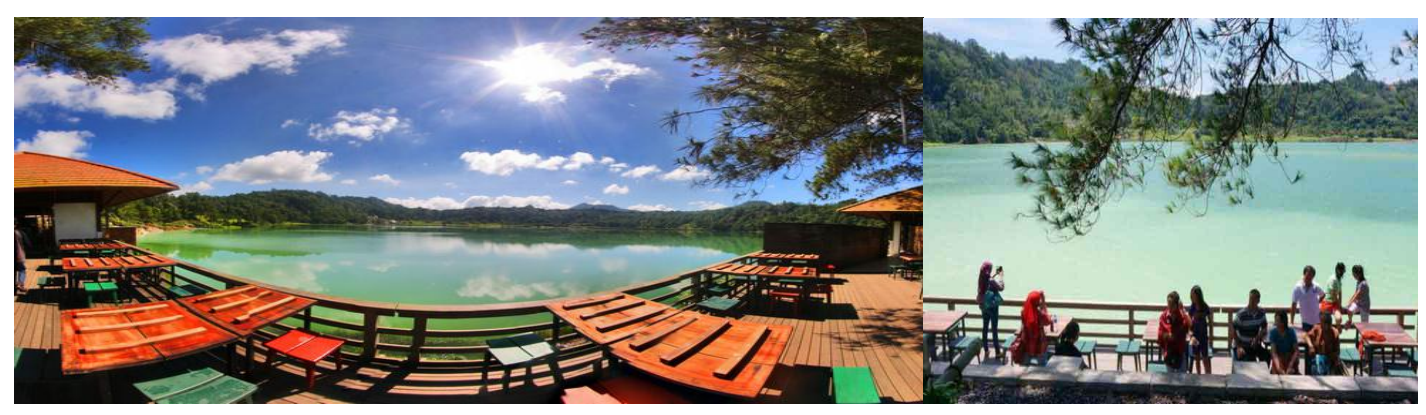

Gambar 11. Danau Linow

\section{Gunung Mahawu}

Gunung Mahawu terletak di pinggir Kota Tomohon. Gunung ini merupakan tempat wisata yang tepat untuk wisatawan yang senang melihat keindahan alam, tetapi tidak ingin mendaki terlalu jauh. Hanya perlu mendaki selama sepuluh menit di tangga yang sudah diperkeras dan bagus, untuk bisa sampai ke kawah gunung. Berkunjung ke Kawah Gunung Mahawu merupakan pilihan yang tepat jika kita sudah puas berjalan-jalan di taman bunga dan ingin melihat kedalaman kawah yang eksotis. Pemandangan berupa kawah Gunung Lokon, gunung Manado Tua, pulau Bunaken, kota Tomohon dan Manado bisa terlihat jika wisatawan berkeliling di jalan setapak di bibir bawah.

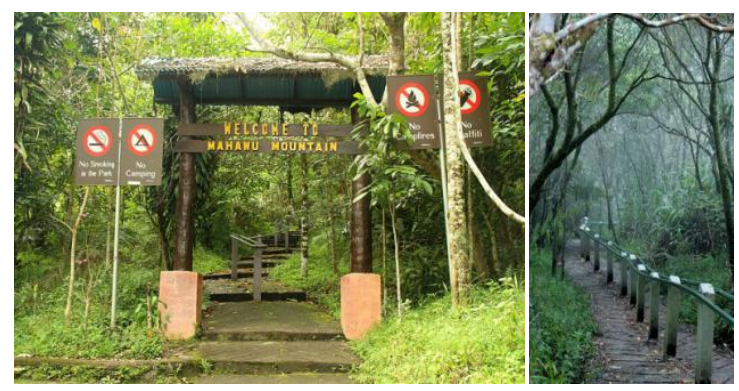

Gambar 12. Gunung Mahawu

\section{Taman Margasatwa Tandu Rusa}

Kebun binatang ini terletak di Kota Bitung. Lokasinya persis ditepi Selat Lembeh sehingga sering juga dimanfaatkan untuk rekreasi pantai.Salah satu hewan khas dan langka yang menghuni Taman ini adalah tarsius. Tarsius adalah satwa langka lucu yang aktif pada malam hari dengan tinggi sekitar $15 \mathrm{~cm}$, ekor panjang, dengan mata bulat besar yang konon tidak mampu berkedip. Hewan yang bisa berkembang biak dengan baik di Filipina dan Sulawesi Utara ini tampak lucu dan seram dengan bola mata bulat besar yang dimilikinya.

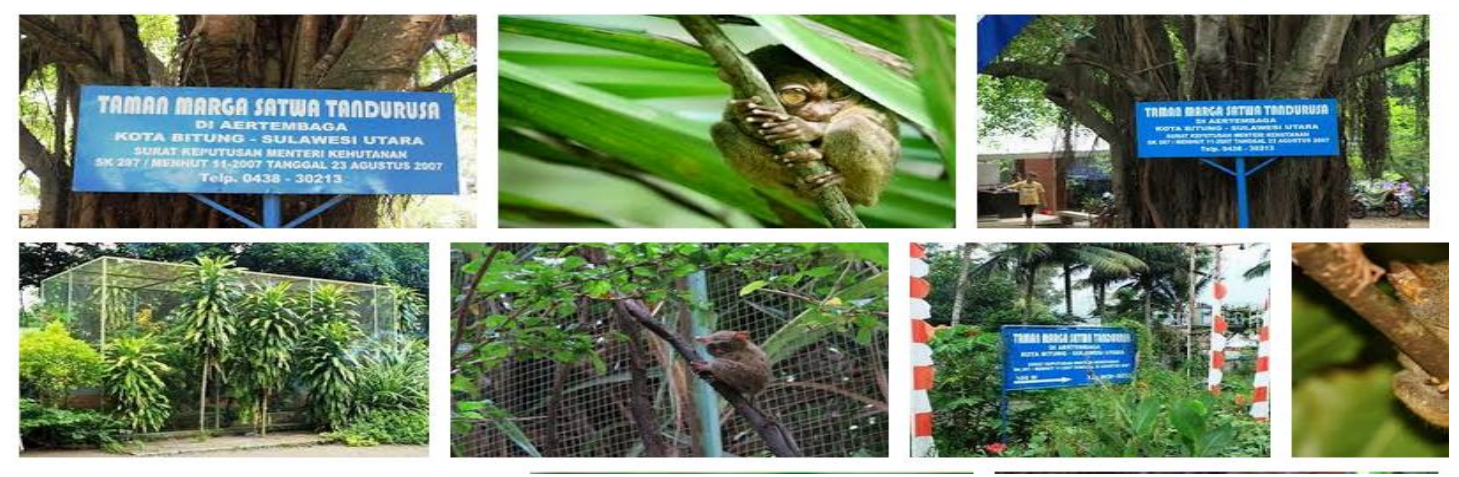

Gambar 13. Taman Margasatwa Tandu Rusa 


\section{Pulau Lembeh}

Pulau kecil yang terletak di Kota Bitung ini tidak terlalu jauh dari Manado.Tempat ini tidak kalah indahnya dengan Pulau Bunaken. Disini terdapat 88 Titik Selam yang indah menunggu kita. Bagi para penggemar snorkel, menyelam, dan fotografi, tempat ini wajib dikunjungi. Kita juga bisa berkeliling tempat wisata di sekitar Pulau Lembeh dengan menyewa perahu untuk berkeliling antar pulau dan kesekitar pulau ini. Untuk yang tidak terlalu suka kegiatan air seperti diving dan snorkeling, bisa juga berfoto-foto di sekitar pulau yang airnya jernih.

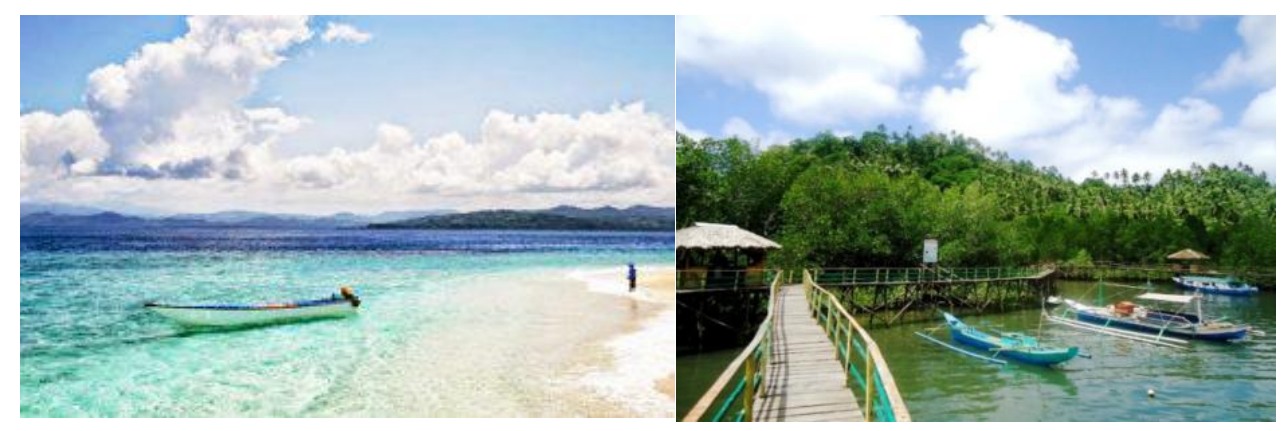

Gambar 14. Pulau Lembeh

\section{Danau Tondano}

Danau Tondano adalah danau terluas di Provinsi Sulawesi Utara. Danau ini diapit oleh Pegunungan Lembean, Gunung Kaweng, Bukit Tampusu, dan Gunung Masarang. Danau ini dilingkari oleh jalan provinsi, yang menghubungkan Kota Tondano, Kecamatan Tondano Timur, Kecamatan Eris, Kecamatan Kakas, Kecamatan Remboken, dan Kecamatan Tondano Selatan. Danau ini merupakan danau penghasil ikan air tawar seperti ikan mujair, pior/kabos, payangka wiko (udang kecil), nikesepat siang (arwana), tawes, pongkor, bontayan, lobster hitam, gurame kupu-kupu, dan karper. Luas danau ini 4.278 ha, dan terdapat pulau kecil bernama Likri dan pulau Papalembet. Dari tepi Danau Tondano terlihat jelas Gunung Kaweng. Konon danau ini terjadi karena letusan yang dahsyat karena ada kisah sepasang insan manusia yang berlainan jenis melanggar larangan orang tua untuk kawin (bahasa Minahasa: kaweng) dengan nekat lari (tumingkas) di hutan. Sebagai akibat melanggar nasihat orang tua maka meletuslah kembaran Gunung Kaweng tersebut, sehingga menjadi Danau Tondano. Danau Tondano mempunyai objek wisata yang terkenal, yaitu "Sumaru Endo" Remboken, Resort Wisata Bukit Pinus, dan Gua Tikus Tasuka. Dari tepian danau Tondano, kita dapat menuju puncak Bukit Lembean dan memandang keindahan Laut Maluku (di sebelah timur), kawasan Tondano Pante (Kecamatan Kombi), dan Kabupaten Minahasa. Di kawasan wisata Danau Tondano ini juga sering diadakan pesta nelayan. Seperti lomba dayung, lomba perahu hias, lomba tangkap ikan tanpa alat, serta parade perahu bolotu.

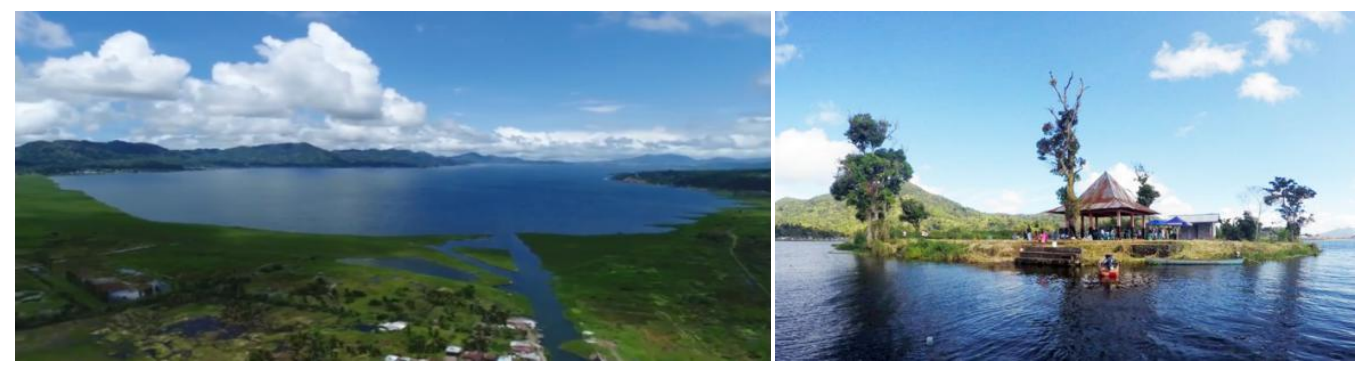

Gambar 15. Danau Tondano 


\section{Bukit Kasih}

Bukit Kasih terletak di $50 \mathrm{~km}$ sebelah selatan Kota Manado, tepatnya berada di desa Kanonang, Kabupaten Minahasa. Bukit Kasih adalah bukit belerang yang masih aktif dan memiliki atmosfir yang dingin. Dibangun pada tahun 2002 sebagai pusat spiritual di mana para penganut agama dari berbagai agama dapat berkumpul, bermeditasi dan beribadah berdampingan di bukit tropis yang rimbun dan berkabut. Pemandangan di sekitar Bukit Kasih masih sangat asri dan hijau. Bukit ini disebut Bukit Kasih karena di situlah orangorang dari berbagai agama dapat berkumpul dan berdoa sesuai dengan kepercayaan agama mereka sendiri dalam harmoni dan damai. Selain itu, Bukit Kasih merupakan simbol perdamaian dan kerukunan antar umat beragama. Ada lima rumah ibadah di sini : Gereja Katolik, Gereja Kristen, Vihara, Masjid, dan Kuil Hindu yang dibangun di puncak kedua. Di pintu masuk Bukit Kasih terdapat sebuah tugu toleransi setinggi 22 meter. Di dalam tugu tersebut terdapat kutipan simbol dan kutipan dari masing-masing agama. Tugu ini juga merupakan monumen untuk mengingatkan akan toleransi dalam kehidupan beragama. Pada puncak pertama terdapat salib putih setinggi 53 meter yang bisa dilihat bahkan dari pantai Boulevard di Manado. Selain itu, tempat ini diyakini sebagai tempat asalnya asal suku nenek moyang Minahasa, Toar dan Lumimuut. Wajah mereka diukir di lereng bukit di bawah puncak kedua. Wajah tersebut diukir dengan maksud agar masyarakat Minahasa tidak lupa akan nenek moyang mereka. Untuk mencapai Bukit, pengujung harus menaiki anak tangga yang cukup panjang. Di beberapa titik jalur anak tangga terdapat kolam belerang di sisi kiri dan kanan. Setibanya di puncak, pengunjung dapat dengan leluasa menyaksikan pemandangan yang luar biasa. Kemudian, pengunjung dapat melihat lebih dekat keberadaan kelima rumah ibadah di puncak ini. Di salah satu tempat ibadah tersebut, anda bisa menyempatkan diri untuk beribadah atau berdoa sesuai dengan kepercayaan anda. Bukit Kasih memiliki fasilitas seperti warung-warung yang menjual berbagai makanan dan minuman, penjualan suvenir, kolam air panas yang alami, jasa shooting foto dan toilet.

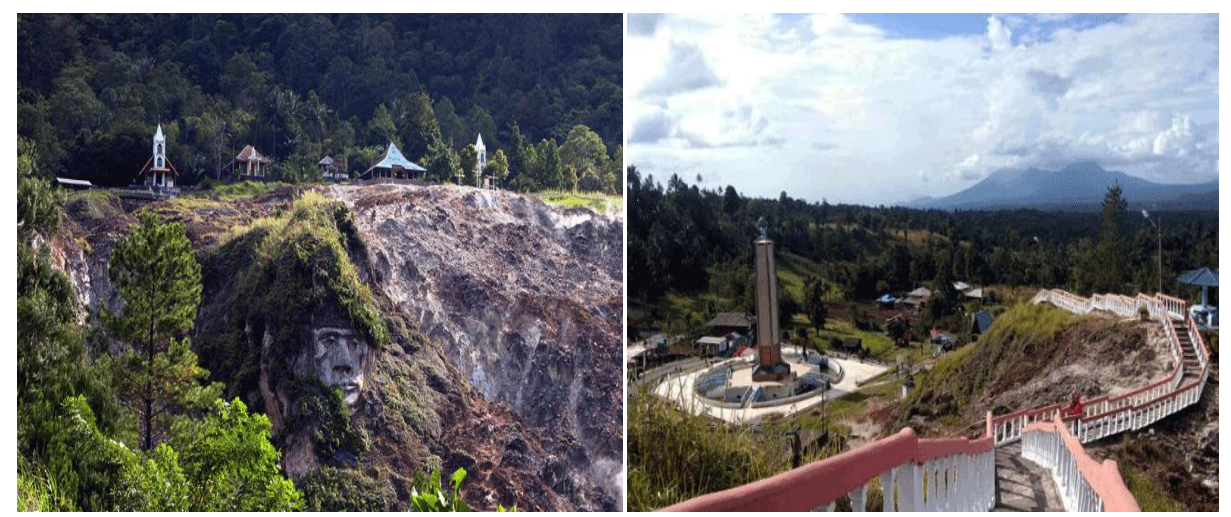

Gambar 16. Bukit Kasih

\section{Arung Jeram Sawangan}

Di Kabupaten Minahasa Utara, terdapat tempat olahraga arung jeram yang sangat menantang, bernama Wisata Arung Jeram Sawangan, di Sungai Sawangan. Sungai Sawangan terkenal memiliki lintas jeram yang sangat baik, sehingga diperlukan penakluk yang tangguh untuk melalui setiap lintasannya. Dua belas area pusat jeram yang berada di sungai Sawangan, pastilah menambah keseruan saat bermain olahraga menantang yang satu ini. Terdapat 2 titik mulai di sungai tersebut, titik mulai pertama berada di PLTA Tanggari dengan jarak tempuh 12 km, serta yang kedua di River Park Sawangan dengan jarak tempuh $6 \mathrm{~km}$. 


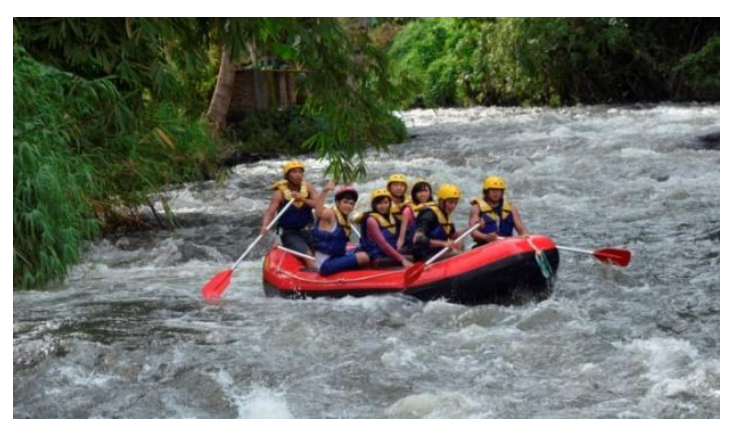

Gambar 17. Arung Jeram Sawangan

\section{Waruga Sawangan}

Salah satu situs peninggalan sejarah yang menjadi andalan Tujuan Utama Wisata di Sulawesi Utara adalah Waruga Sawangan. Masyarakat Utara, khususnya suku Minahasa memiliki tradisi yang unik dalam pemakaman yakni dengan menguburkan orang yang telah meninggal kedalam wadah bernama waruga. Waruga memang tersebar di berbagai tempat di Sulawesi Utara, tetapi di desa Sawangan ini, wisatawan bias melihat Waruga dalam jumlah yang banyak. Waruga sendiri terdiri dari dua bagian, yaitu bagian badan dan kepala atau penutup. Seluruhnya terbuat dari batu utuh, dan bagian badan umumnya berbentuk persegi empat dengan ruang kosong di bagian tengah untuk meletakkan jenazah yang akan dimakamkan. Waruga Sawangan berlokasi di Desa Sawangan, sekitar 45 menit dari Kota Manado.

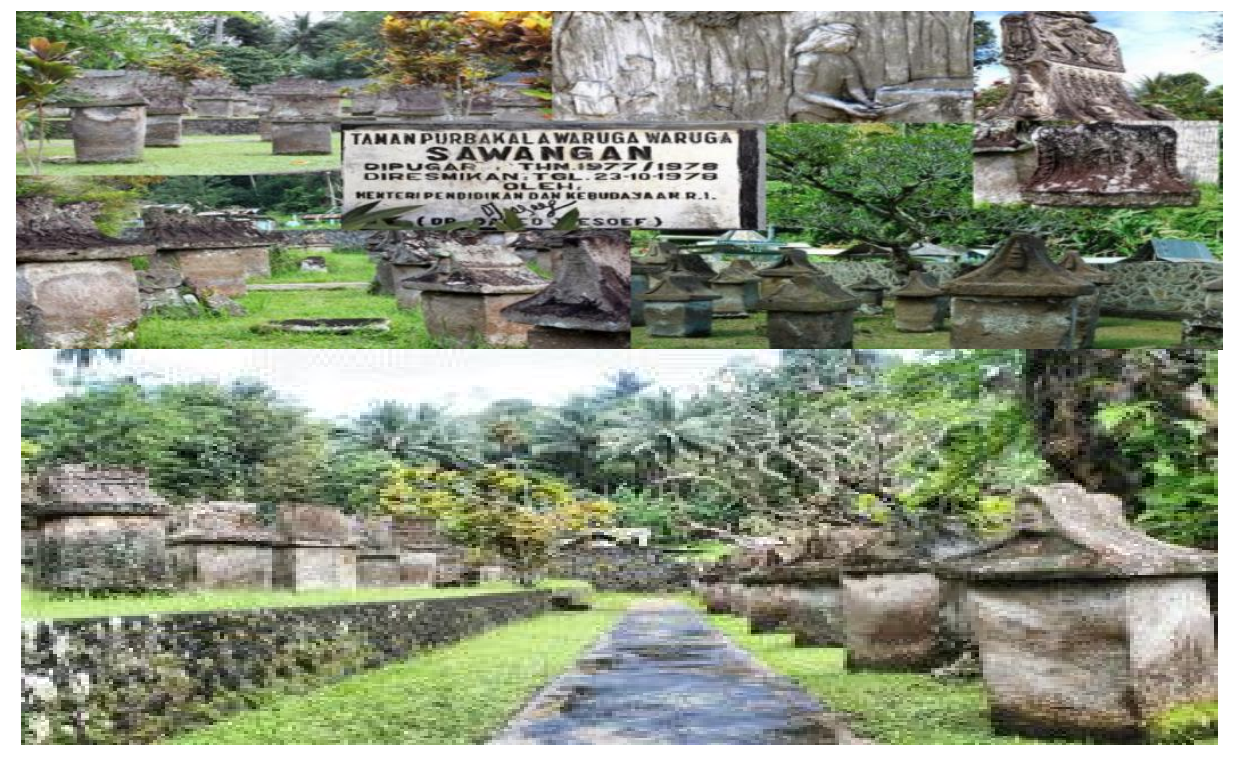

Gambar 18. Waruga Sawangan

\section{Pulau Lihaga}

Pulau Lihaga, yang terletak di Kabupaten Minahasa Utara, ini bernuansa eksotis dan pengunjung bias mendapat pantai pasir putih dengan air yang biru hijau dan jernih. Ombak yang bersahabat dan tenang memang membuat pengunjung tidak bisa surfing, tetapi wisatawan bias bersantai, berjemur dan bermain air di pinggir pantai yang indah ini. Pulau Lihaga memang belum mempunyai banyak pengunjung karena belum terkenal, tetapi pemandangan di Pulau Lihaga bias diadu dengan tempat wisata di Kepulauan Maladewa. 


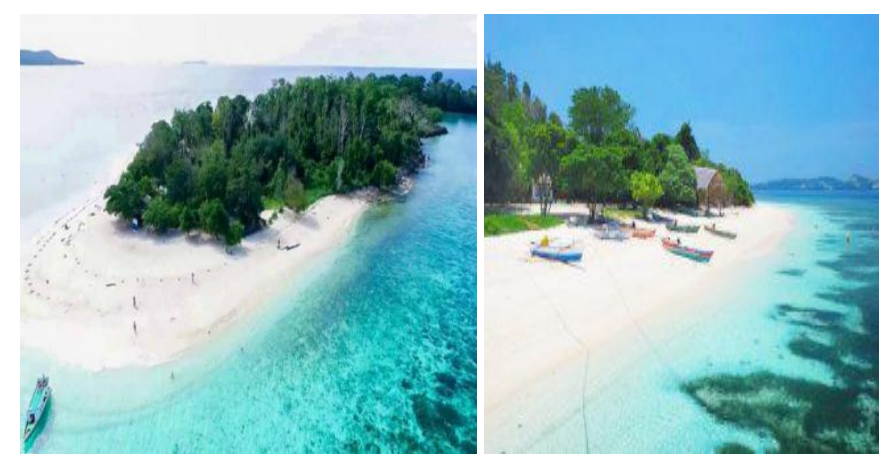

Gambar 19. Pulau Lihaga

\section{Taman Laut Tumbak}

Obyek Wisata Air Taman Laut Tumbak bisa diadu dengan Bunaken dan Pulau Lembeh. Tempat yang berjarak sekitar 3 jam dari Manado dan terletak di kabupaten Minahasa Utara ini cocok untuk memuaskan hobi wisatawan yang menyukai wisata di bawah air. Di Taman Laut Tumbak terdapat 20 titik Selam dan Snorkel yang patut dicoba. Beberapa diantaranya adalah Napo Kipas, Bohaga Mangrove, Bohaga Kecil, Taman Karang, dan Pintu Samudra. Meskipun memiliki keindahan yang luar biasa, Taman Laut Tumbak ini tidak terlalu dikenal oleh wisatawan umum. Maka dari itu, kita bisa berwisata dengan tenang dan menikmati tempat yang indah dan juga menakjubkan ini.

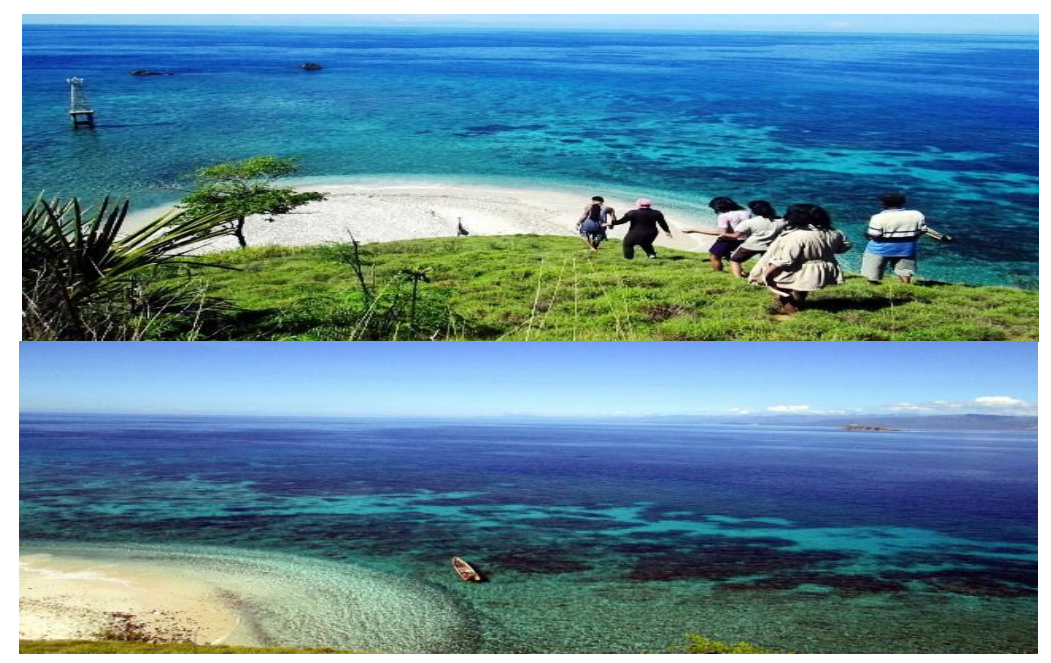

Gambar 20. Taman Laut Tumbak

\section{Air Konde}

Tujuan Wisata Air Konde adalah Wisata Alam berupa Mata Air dengan Kolam Sungai yang terletak di Kabupaten Minahasa Tenggara.Mata air yang berada di Desa Wawali, Ratahan ini tak hanya jadi tempat santai warga lokal, tapi warga dari luar daerah kabupaten pun kian ramai datang.Mata air yang terletak di pinggiran hutan ini menjadi pesona baru di Kabupaten Minahasa Tenggara. Memasuki kawasan mata air, langsung disambut suara gemuruh air sungai yang mengalir deras di antara bebatuan.Akses jalan masuk pun kian mantap, kendaraan roda empat bisa masuk sampai ke dalam. Dari tempat parkir kendaraan tinggal berjalan sekitar 100meter sudah bisa melihat sungai kecil aliran dari mata Air Konde. 


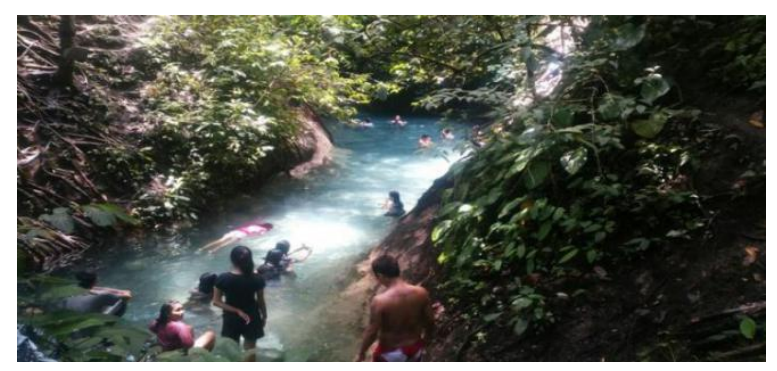

Gambar 21. Air Konde

\section{Identifikasi Tingkat Popularitas Destinasi Wisata}

Bagi keperluan Perencanaan Pengembangan Pariwisata, Popularitas Destinasi Wisata perlu untuk diperingkat. Pemeringkatan dilakukan berdasarkan Urutan Peringkat yang didapat dari beberapa Artikel di Masmedia (Anonim 2019; Falah 2019; TripAdvisor 2019; Trisandy 2018) dan dari beberapa Biro Perjalanan di Kota Manado yang menyelenggarakan Paket Wisata Sulawesi Utara. Pemeringkatan berdasarkan Tingkat Popularitas Obyek Wisata bagi Wisatawan disampaikan pada Tabel 2 sebagai berikut.

Tabel 2. Tingkat Popularitas Destinasi Wisata bagi Wistawan

\begin{tabular}{rlll}
\hline \multirow{2}{*}{ No } & Data Artikel & Wis ata Domes tik & Wis atawan Mancanegara \\
\hline 1 & Manado Adventure & Taman Nasional Bunaken & Taman Nasional Bunaken \\
2 & Taman Nasional Bunaken & Danau Linow & Manado \\
3 & Pulau Manado Tua & Bukit Kasih & Taman Nasional Tangkoko \\
4 & Pulau Siladen & Danau Tondano & Tomohon \\
5 & Manado Skyline & Pasar Esktrim Tomohon & Danau Linow \\
6 & Museum Negeri & & Pasar Ekstrim Tomohon \\
7 & GPI Waterpark & & \\
8 & Gunung Tumpa & & \\
9 & Jembatan Sukarno & & \\
10 & Air Terjun Kali & & \\
\hline
\end{tabular}

\section{Identifikasi Kunjungan Wisatawan}

Pada kurun waktu Tahun 2014 - 2017 Jumlah Kunjungan Wisatawan Mancanegara naik dengan sangat pesat, sebanyak 460\%, dari 17.279 lunjungan ke 79.377 kunjungan (BPS Sulut 2017). Perkembangan Jumlah Kunjungan disampaikan pada Tabel-Gambar 1 sebagai berikut.

Tabel-Gambar 1. Perkembangan Jumlah Kunjungan Wisatawan Mancanegara

\begin{tabular}{ccr}
\hline No & Tahun & Jumlah \\
\hline 1 & 2013 & 19,917 \\
\hline 2 & 2014 & 17,279 \\
\hline 3 & 2015 & 19,465 \\
\hline 4 & 2016 & 40,624 \\
\hline 5 & 2017 & 79,377 \\
\hline
\end{tabular}

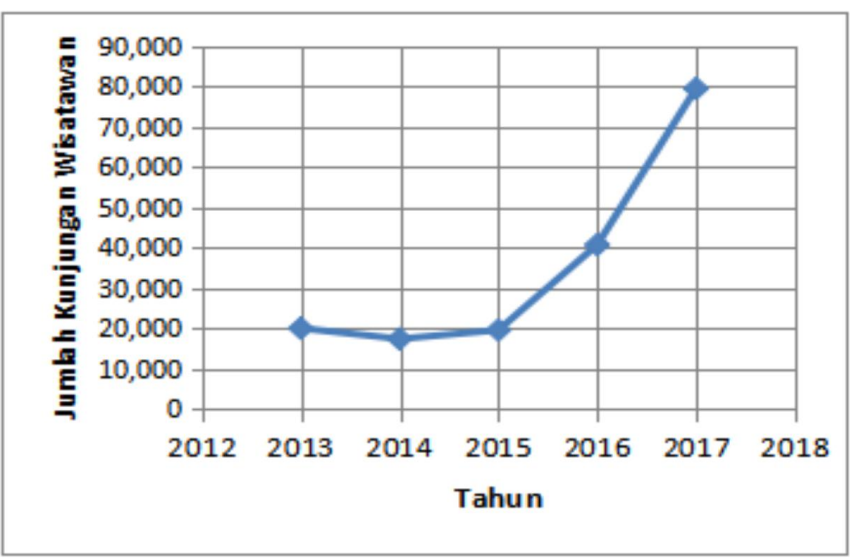


Sebaran negara asal wisatawan mancanegara, pada tahun 2017, didominasi oleh Wisatawan dari Tiongkok sebesar 79,1 \%, sedangkan wisatawan dari Singapura, Jerman dan Amerika masing-masing sebesar sekitar 2\% (BPS Sulut 2017). Lama tinggal wisatawan secara umum adalah 6 hari 5 malam bagi wisatawan dari China dan 2 minggu bagi wisatawan Eropa. Wisatawan Tiongkok kebanyakan tinggal di beberapa hotel tertentu di Kota Manado, sedangkan wisatawan dari Eropa kebanyakan tinggal di resor-resor di Pulau Bunaken dan Kota Tomohon. Sebaran negara asal wisatawan disampaikan pada Tabel 2 sebagai berikut.

Tabel 2. Sebaran Negara Asal Wisatawan Manca Negara

\begin{tabular}{crrr}
\hline \multirow{2}{*}{ No } & \multirow{2}{*}{ Negara } & \multicolumn{2}{c}{ Jumlah Prosentase } \\
\cline { 3 - 4 } & & orang/th & $\%$ \\
\hline 1 & Tiongkok & 62,791 & 79.1 \\
2 & Singapura & 1,795 & 2.3 \\
3 & Jerman & 1,760 & 2.2 \\
4 & Amerika & 1,440 & 1.8 \\
5 & Inggris & 879 & 1.1 \\
\hline \multicolumn{2}{l}{ sumber : BPS Sulut 2017}
\end{tabular}

Wisatawan Domestik kebanyakan berasal dari 3 kota besar di Pulau Jawa : Jakarta, Bandung dan Surabaya. Lama tinggal Wisatawan Indonesia kebanyakan berkisar 4 hari 3 malam di berbagai hotel di Kota Mando, seperti hotel Peninsula dan hotel Four Points.

\section{KESIMPULAN}

Penelitian identifikasi obyek wisata ini telah berhasil diselesaikan. Beberapa kesimpulan pokok bisa dituliskan sebagai berikut.

- Obyek Wisata Provinsi Sulawesi Utara terutama tersebar di wilayah Kota Manado, Kota Tomohon, Kota Bitung, Kabupaten Minahasa, Kabupaten Minahasa Utara, dan Kabupaten Minahasa Tenggara.

- Obyek Wisata Provinsi Sulawesi Utara sangat bervariasi dari Wisata Alam, Wisata Agro, Wisata Budaya, Wisata Religi, dan Wisata Kuliner.

- 10 Destinasi Wisata terpopuler : Manado Adventure Park, Taman Laut Nasional Bunaken, Pulau Manado Tua, Pulau Siladen, Para Layang Manado, Museum Negeri, GP Waterpark, Gunung Tumpa, Jembatan Soekarno, dan Air Terjun Kali.

- Wisatawan Mancanegara sebagian besar berasal dari Tiongkok.

Penelitian ini perlu dilanjutkan antara lain untuk mengkaji gambaran umum sistem pariwisata, bentuk-bentuk perjalanan wisata, asal para wisatawan, pengurutan daya tarik tiap obyek wisata dengan lebih teliti dengan membedakan antara bagi wisatawan domestik dn wisatawan mancanegara, daya dukung obyek wisata, aksesibilitas obyek wisata, kepuasan wisatawan, fasilitas perhotelan, obyek wisata kuliner, manajemen pariwisata, dan berbagai aspek pariwisata yang lain.

Notes. Makalah ini merupakan langkah pertama bagi Pemahaman Pariwisata di Provinsi Sulawesi Utara, Pemikiran Pengembangan Pariwisata di Provinsi Sulawesi Utara, serta bagi Pengembangan Ilmu Manajemen Pariwisata.

\section{DAFTAR PUSTAKA}

Anonim (2017). Neraca Satelit Pariwisata Nasional (Nesparnas) 2017. Kementerian Pariwisata. Jakarta.

Anonim (2019). "5 Tempat Wisata yang Luar Biasa Indah di Sulawesi Utara”. KSM Tour. https://ksmtour.com/informasi/tempat-wisata/sulawesi-utara. 
Aryunda, Hanny (2011). "Dampak Ekonomi Pengembangan Kawasan Ekowisata Pulau Seribu". Jurnal Perencanaan Wilayah dan Kota, Vol. 22, No. 1, April 2011, Hal. : 1-16.

BPS Sulut (2017). Statistik Wisatawan Mancanegara Provinsi Sulawesi Utara 2017. Badan Pusat Statistik Provinsi Sulawesi Utara. Manado.

Falah, Jihad Hayatul (2019). “35 Tempat Wisata di Manado Terbaru yang Lagi Hits 2019”. Wisata Lengkap. https://wisatalengkap.com/tempat-wisata-di-manado.

Mudrikah, A., et al. (2014). "Kontribusi Sektor Pariwisata terhadap GDP Indonesia Tahun 20042009". Economics Development Analyses Journal, Vol. 3, No. 2, Juni 2014.

Patera, I Made \& Suardana, I Wayan (2015). "Model Hubungan Pariwisata, Kinerja Perekonomian dan Kemiskinan di Kabupaten Badung, Bali”. Piramida, Vol. XI, No. 2, Desember 2015, Hal. : 95-105.

Sanjaya, Ketut (2006). "Sektor Jasa sebagai Motor Pembangunan Daerah". Diskusi Terfokus ISEI, Kantor Bank Indonesia Denpasar, 18-19 Mei 2006.

Soemitro, R.A.A. \& Suprayitno, H. (2018). "Pemikiran Awal tentang Konsep Dasar Manajemen Aset Fasilitas". Jurnal Manajemen Aset Infrastruktur \& Fasilitas, Vol. 2, Sup. 1, Juni 2018, Hal. : 1-13.

Subardini (2017). “Analisis Kontribusi Sektor Pariwisata terhadap Produk Domestik Regional Bruto Jawa Timur”. JIABI - Jurnal Ilmiah Administrasi Bisnis dan Inovasi, Vol. 1, No. 2, 2017, Hal. : 102-114.

Suprayitno, H. \& Soemitro, R.A.A. (2018). "Preliminary Reflexion on Basic Principle of Infrastructure Asset Management". Jurnal Manajemen Aset Infrastruktur \& Fasilitas, Vol. 2, No. 1, Maret 2018, Hal. : 1-9.

Thaib, Hiramsyah S. (2017). "Strategi Pengembangan Kepariwisataan Indonesia". Seminar Kerangka Fiskal Pendanaan Pariwisata Berkelanjutan dan Pengelolaan Sampah/Limbah Perkotaan, Jakarta, 18 Desember 2017.

Trip Advisor (2019). "Obyek Wisata di Sulawesi Utara”. Trip Advisor. https://www.tripadvisor.co.id.

Trisandy, Andy (2018). "10 Tempat Wisatandi Manado Terbaru dan Paling Hits buat Dikunjungi". IDN Times. https://www.idntimes.com/travel/destinations.

TutorialsPoint (2016). Tourism Management. Tutorials Point (I) Pvt. Ltd. Hyderabad.

UU 10/09. Undang-Undang Republik Indonesia Nomor 10 Tahun 2009 tentang Kepariwisataan.

Wahyuni, Sri (2019). "Analisis Pariwisata Budaya dalam Pengembangan Aset Lokal Perayaan Upacara Adat Dahau di Kabupaten Kutai Barat Provinsi Kalimantan Timur". Jurnal Manajemen Aset Infrastruktur \& Fasilitas, Vol. 3, No. 1, Maret 2019, Hal. : 25-35.

WTTC (2018). Travel \& Tourism Economic Impact 2018 World. World Travel \& Tourism Council. London. 